JELTL (Journal of English Language Teaching and Linguistics) e-ISSN: 2502-6062, p-ISSN: 2503-1848

2018, Vol. 3 (2)

www.jeltl.org

\title{
The Uniqueness Formation of Papuan Malay in Morphologically
}

\author{
Herlandri Eka Jayaputri \\ Magister Program of Applied Linguistics, Yogyakarta State University \\ Colombo Street No.1, Caturtunggal, Depok, Yogyakarta 55281, Indonesia \\ Herlandrieka@gmail.com \\ Dwiyanto Djoko Pranowo \\ Magister Program of Applied Linguistics, Yogyakarta State University \\ Colombo Street No.1, Caturtunggal, Depok, Yogyakarta 55281, Indonesia \\ dwiyanto@uny.ac.id
}

\begin{abstract}
Indonesia has many Malay speakers and it spreads to Papua with the influence of Ambon and Indonesian becomes one of the variations in the Papuan Malay dialect. Papuan itself is the home of 275 languages that are 218 non-Austronesian or Papuan (79\%) and 57 languages are Austronesian (21\%) (Lewis et al. 2013 cited in Kludge, 2014). Moreover the influence of Ambon and the North Moluccan Malay, and Indonesia played an important role especially in the formation of Papuan Malay (Paauw, 2009). Papuan Malay language is spoken by the inhabitants of the West Papua and uses as the daily language (Kludge, 2014). The formation of Papuan Malay has the uniqueness because it deletes some syllables but does not have the impact of the meaning. This study aims to know and explain the process of clipping word of Papuan Malay as well as their word classes. The Data come from the video of MOB Papua. Besides that, the method used in this study is a Padan method with comparing of other langue. Therefore, this study appears the history and the role of Papuan Malay as well as compare the Indonesian with Papua Malay to find the clipping word process in Papuan Malay.
\end{abstract}

Keywords: Papuan Malay, history of Papuan Malay, word formation, the clipping word, morphological study 


\section{INTRODUCTION}

Austronesian languages reach half of the world that spread from Madagascar to Easter Island, from Taiwan, and Hawaii to New Zealand. The presence of Austronesian families borns in the 17th century when the Polynesian words were combined with Malay words. Indonesia has many Malay speakers. It grows rapidly to the various regions mainly in Papua. the combination of Papuan and Austronesian languages as well as Indonesian and the other regional language lives in Papua that appears the Papuan Malay (Kludge, 2014, p. 37). It becomes the speech used by speakers on the western part of the island of Papua New Guinea that concludes to the Indonesia territory are Papua and the West Papua (Kludge, 2014, p. 1).

The number population of Papua and the West Papua provinces in 2010, based on the statistical agency of Indonesia (BPS), is 2.833.381 form the Papua province and 760422 from the areas of West Papua. The data is not elaborated on how many speakers of Papuan Malay. The previous studies give the various numbers of Papuan Malay speakers. Donohue, Mark \& Sawaki (2007 cited in Kludge, 2014, p. 5) mentioned there are 1 million speakers. While Paauw (2009, p. 71) estimated that there are 2.2 million speakers. In addition, Kludge (2014) stated that the number speakers are 500,000 who use Papuan Malay as the first language. However, the transmigration process to Papua is a part of the main role in developing the Papuan Malay of Malay Papuan. Kludge (2014) assumed that the Papuans living in the coastal area can speak Malay and non-Papuans are also likely to talk the Papuan Malay.

Papuan Malay spreads from the speakers in the area of the West Papua such as Sorong, Fak-fak, Manokwari, Serui, Sarmi, Jayapura, Timika, Merauke. It originates from the pidginization and nowadays becomes the lingua franca because they used it in their daily life (Kludge, 2014). The Application of Indonesian as the official language in Indonesia and the large transmigration that causes Papuans have to use Indonesian to communicate to the others. However, culturally it is not possible to use the Indonesian speaking standards because of the threat of variations in linguistic systems. for instance, a Papuan come from Serui island (the northern part of Papua) can speak Javanese and Indonesian fluently but there is a difference in rhythm and pronunciation because of the first language influence (Supardi, 2014). In addition, Indonesian becomes a role of the development of Papuan Malay (Supardi, 2014). Some words in Papuan Malay consists of Indonesian and the others regional language so it becomes an interesting study in the linguistic world. Besides the Papuan Malay words is formed in the clipping word but still have the same meaning of them such as the words, noun, verb or the word negation.

Some studies of Papuan Malay have been done by the experts. The study of Moeliono (1963) refers to Indonesian as an Indonesian accent that focuses on the area of West Papua. It spread on the urban society and is used by the Dutch colonial government in the western Papuan. Thus, it is used as a lingua franca in the formal or informal situation. Moreover, Gau (2011) concerns about the diversity of 
language and the role of Malay in Papua historically and linguistically. He found that Papuan Malay acts as a communication language (Lingua franca) among ethnic groups. While Supardi (2014) reported that Papuan Malay has different types of phonemic and morphemic systems in the other regional dialects or Indonesian itself. In addition, Kludge (2014) studied the linguistic system of Papuan Malay. She described the linguistic system of Malay Papuan in phonology, morphology, phrase, and clause. However, she did not discuss deeply the formation of words through the word borrowing process. Therefore, this study concerns the word formation of Papuan Malay through the clipping word process. Therefore, this study reveals some aspects as follows: 1) the number of Papuan Malay words through the clipping word, 2) the type of Papuan Malay word, 3) the morphological analysis on Papuan Malay with the clipping word process.

\section{LITERATURE REVIEW}

\subsection{Theoretical Perspective I: The History and role of Papuan Malay}

Papuan Malay has a role as the communication language between the ethnic groups and speakers that reach approximately about 271 languages. Papuan Malay is channeled from Mollucas Malay which had the political or economic relations among them (Agus A Alua; Ali Afudy; Presidium Dewan Papua (PDP). Sekretariat.; Sekolah Tinggi Filsafat Teologi (STFT) Fajar Timur. Biro Penelitian., 2006). Malay has a long history as a trading language on the Malay peninsula and Indonesia. It developed from the Javanese and Mollucas trading routes (Seram, Tidore). Malay in Mollucas spread to West Papua which is now called Papuan Malay (Adelaar, K. Alexander \& Prentice, 1996; Collins, 1998; Paauw, 2009). The presence of Malay on the coastal of the West Papua began on the fourteenth century (Rowley, 1972). In 1793, British were the first explorer to Dorey, now called Merauke, for two years which Dorey was still under the influence of Sultan Tidore. This era, Malay became the regional language that is used to communicate for a long time (Velven, 1995 cited in Kludge, 2014). However, in the ninth century, when the French explorer and rear admiral Dumont d'Urville settled in Dorey (Manokwari) on September 1872, he found that Papuans, inhabitants living in Dorey, rarely know Malay. Besides, they have the upper class who can speak Malay well and the others less fluent (1833: 606, in Kludge, 2014). Conversely, in 1893, a Protestant missionary named Bink ventured into Humboldt Bay reported that the presence of Malay traders from Ternate (Bink 1894 in Kludge, 2014). Another observer named Wichmann told that the presence of Malay trades that were living on Debi Island in Jautefa Bay (Wichman, 1917 in Kludge, 2014). Hasselt (1926 cited in Kludge, 2014) also reported that when he visited Jamna Island, located in the north coast between Sarni and Jayapura, Papuans could speak Malay, as they generally communicate with the traders.

After the second world war, the Dutch government recruited additional personalities to West Papua that came from the others regions such as Sulawesi, Flores, Timor, and the Kei Island (Adelaar, K. Alexander \& Prentice, 1996; 
Donohue, Mark \& Sawaki, 2007; Roosman, 1982). In the same time, increasing the number of Papuans received the primary school. In addition, Dutch established a school to train Papuans as the public services, government employees, teachers, and police officers. During this period, the standard Malay became the official language in various fields as well as religious domain (Adelaar, K. Alexander \& Prentice, 1996; Chauvel, 2002; Donohue, Mark \& Sawaki, 2007). However, after West Papua became part of Indonesia in 1963, Indonesian became the official language used in various fields such as education, mass media, and religious (Kludge, 2014).

Through the description, there are two aspects that are Ambon and the North Moluccan Malay, and Indonesia played an important role especially in the formation of Papuan Malay (Paauw, 2009). Secondly, Papuan Malay are influenced by various regions which have 275 other languages and non-Austronesian languages. In linguistically, each language has different grammatical and phonological systems and can influence the Malay speech with individuals or communities (Paauw, 2009). The other side, the important role of Malay with its variants bridge the gap between the regional language and modern Indonesian. In addition, it gives the good impact for the using of Indonesia orally. The Malay dialect has become a dominant variant, which is not only spoken in coastal areas, but also in all inland areas.

Using of Malay and Indonesian have the different terms. Though from the perspective of dialectology, Malay is used by the Papuans and Indonesians. The Malay term refers to a Malay variety such as Malay of Jakarta, Bangka, Manado, Makassar, Ambon, Ternate, Kupang, Loloan (Muhadjir, 1999; Nothofer, 1997; Collins, 2007a; 2007b; Jauhari, 2007; Sumarsono, 1990 cited in Supardi, 2014). These differences are grouped in phonological, morphological, grammatical and semantic forms. Moreover, Indonesian is the official language, standard, In Papua, Indonesian is the official language and standard. Whereas Papuan Malay become the informal language (Roosman, 1982; Suharno, 1979). The meaning of standard in this context is the speech variety of a community which is ratified as the norm of the society (Dittmar, 1976, p. 8). The act of norm legalization is done through the consideration of values that are based on the socio-political.

Papuan Mallay relates to the Papuan community dialect. In linguistically, it deals with phonetics on suprasegmental sounds. Based on Verhaar (2012, p. 56), among the language sounds, there is not related to the sequential sound "segment" but "accompany" the segmental sounds such as intonation, tone, accent, and pressure or suprasegmental. In Papuan Malay is a dialect that has intonation, tone, and accent which is faster than other regional languages in Indonesia. Besides, a study also concerns about the linguistic features of Papuan Malay. When the outside Papuans hear the form of Papuan Malay, they are going confused such as "Sapu kaki sakit". The word sapu does not mean broom or a thing, but it is included to the complex case as the word $s a$ - means me or saya and $-p u$ means possesive marker or punya. Relating to the case, the linguistics features can help the outside Papuan to understand the Papuan Malay (Supardi, 2014). He also explained the linguistics 
features that are phonemic linguistics system, morphemic linguistics system of Papuan Malay, reduplication of lexical verb (Supardi, 2014, p. 5). Therefore, those aspects can create a new word because the words have cut some syllables but still have the same meaning. It can be analyzed morphologically to know new words formed through the cutting process of the word without having the different meaning.

\subsection{Theoretical Perspective II: The word formation in Morphology}

The linguistic branch discusses word called morphology. Morphology is a linguistic branch that identifies the basic units of language as the grammatical units (Verhaar, 2012, p. 97). According to Katamba (1993:19) stated that morphology is the study of the word structure. Moreover, Morphology is also seen as the study of morphemes and its distribution in the word formation (Nida, 1949). The International Encyclopedia of Linguistiucs (1992) stated that traditionally the extent of Morphology includes two aspects that are inflectional morphology studies how words vary in expressing grammatical differences in a sentence and derivational morphology studies the principles governing the word formation without referring to a particular grammatical role in a sentence.

The word formation analyzes the arrangement process of the word (Bauer, 1984, p. 12). There are some the word formations that are compounding, derivation, inflection, coinage, conversion, borrowing, blending, clipping, back formation, acronyms, Onomatopoeia so it changes the original form of words or changing the word meaning. However, this study concerns the word formation that has the word cutting (clipping word). Clipping word is a process of the word forming with cutting a part of the word itself at the beginning or end. For example, "Gasoline" becomes "Gas", "Professor" becomes "Prof", "Influenza" becomes "Flu" and the case for the word "situation comedy" becomes "sitcom" that is named clipped compound. Each language must have a word or syllable cut in the formation of the new word. In addition, the clipping indicates the familiarity orally or written (Adams, 1973). Linguistically cannot be obligated in two forms having the same meaning, so it is common in daily language or accent that occurs in the language.

The number of the clipping words in English is approximately about $4.6 \%$ and exceeds the abbreviated number (Cannon, 1987, p. 152). Veisbergs (1999, p. 155) argued that the clipping word can be created from conversations in school and college campus environments such as "graduate" becomes "grad", "examination" becomes "exam", "economics" becomes "econ", "mathematics" becomes "math", and etc. The occupation field also becomes the formation of new words such as "veteran" becomes "vet", "captain" becomes "cap", "helicopter" becomes "copter", "brassier" becomes "bra", and etc.

The shortening process of a word is unpredictable, because it is impossible to predict the syllable number that needs to be cut, whether at the beginning or end of the syllable or the stressed syllable such as the word "photograph" has an emphasis syllabel on "photo", " discotheque "has a stressed syllable on" disco "and a word has 
a length silabel (such as 3, 4, 5 syllables) that can be cut maximal two syllables and if monosilables, such as gymnaesium \& advertisment, must be minimally bimoraic, then becomes "gym" and "ad " (Bauer, 1984). They can be cut because of the stress words and create a new word with various structure patterns (Blevins, 1995 cited in Aziz, 2011, p. 124). In addition, the clipping words does not only change the word base but also change the sound of the word. Nonetheless, any changes of sound and word structure, it does not cause any differences in meaning. (Jamet, 2009; Nurhayati, 2016; Veisbergs, 1999).

Besides, the clipping can occur in a compound word that is called clipped compound. It only cuts the final syllables of each word and compare the multi-word base. It is different with acronym because clipped compound is not enough only a minimal word such as acronym for instance "sitcom" comes from "situation comedy" and "natcom" comes from national communications. Thus, clipping word of English is not limited by the rule of cutting the syllable (eg, limo, pro, hat) (Moehkardi, 2016; Veisbergs, 1999, p. 156). Then, he also grouped the types of clipping words and they are used to analyze the Papuan Malay languages as follows:

- Backclipping

The clipping word occurs in the end of word that is named Backlipping or aposcrapyand it usually happens in English. For examples, doctor becomes doc, laboratory becomes lab, and professor becomes prof. Backclipping. In addition can occur in the compound word such as zoological gardens becomes zoo, permanent wave becomes perm, and public house becomes pub.

- Foreclipping

Foreclipping or frontclipping or aphresis arises in the begining word such as, airplane becomes plane, telephone becomes phone, and helicopter becomes copter. In English this type rarely occurs in the word formation.

- Middleclipping

Middleclipping or syncope occurs in the middle word. This is signed with the using of apostrophe (') such as madam becomes ma'am, spectables becomes specs, and mathematics becomes maths.

- Complex cases

In English, there is a combination in two types of clipping word such as foreclipping and backclipping. For instance, influenza becomes flu, refridgerator becomes fridge and distillery becomes still.

- Clipping and Compounding

Clipping word becomes the element of compound word and it includes to the clipped compound. For example, confidence man becomes con man, and parachute troops becomes paratroops. 
- Two Backclipping

The word formation can occur with combined from the result of backclipping such assituation comedy becomes sit-com, international police becomes interpol dan science fiction becomes sci-fi.

\section{RESEARCH METHODS}

This study, the authors explained the language phenomenon in Papuan Malay especially on the new word formed of the clipping word. The subject of this study is the conversations that occurred on the video of MOB Papua. It is a funny video made by the Papuans. There are ten videos to be analyzed through the speech. The objective is finding the words of Papuan Malay have the clipping word through the MOB Papua video. In addition, this study used the Padan method with compared to the other languages such as the regional languages and Indonesian (Sudaryanto, 2015, p. 30). Through the technique, the researcher recorded the Papuan Malay words and used a hubung banding memperbedakan technique (or HBB technique) (Sudaryanto, 2015, pp. 30-35). After comparing with other languages (Indonesian), the researcher found the differences among them, so the new word formation of Papuan Malay can be revealed.

\section{FINDINGS AND DISCUSSION}

The word list of Papuan Malay (PM) has been presented in metadata mainly in table 1 the word list of PM. Then they are grouped and compared with Indonesian (Ind.) and that is used to find out whether there is a word has the clipping word process or not. The analysis concerns on the Papuan Malay word that have clipping word based on their types such as Backclipping, middle clipping, two backclippings, middle clipping \& backclipping and foreclipping. The description of the processes of clipping word in Papuan Malay word show as follows.

1. Backclipping

Table 2a. The backclipping words of Papuan Malay.

\begin{tabular}{ccc}
\hline Code & \multicolumn{2}{c}{ Word } \\
\cline { 2 - 3 } & Ind. & PM \\
\hline $1 \mathrm{a}$ & Adik & Ade \\
\hline $1 \mathrm{~b}$ & Balik & Bale \\
\hline $1 \mathrm{c}$ & Coba & Co \\
\hline $1 \mathrm{~d}$ & Dengan & Deng \\
\hline
\end{tabular}

Based on Veisbergs (1999), the clipping word occurs in the end of word. It usually happens in English. Thus, this case also occurs in Papuan Malay. The words of table 2a show the backclipping word. Code 1a the word "adik" is a backclipping that becomes "ade". The letters "-ik" in the end of the word "adik" is cut and stressed on "de" becomes "ade". Additionally, the words "Adik (noun)" and "ade (noun)" do not have the shift meaning. They have meant as the young partner in JELTL (Journal of English Language Teaching and Linguistics), 3(2), 2018 
family, and little brother or sister. Code 1b, the word " balik" is the backclipping word. The word "balik" is stressed on the syllable "-lik" and the letters "-ik" in the end of the word "balik" word is cut. Then, it becomes "Bale". The words do not have the shift meaning between "Balik" (verb) and "Bale" (verb). They have meant to move or make something move backwards and back to home or their place. Both of the words do not change the meaning, but change the sound of the words (see (Veisbergs, 1999).

For the code 1c, the word "coba" is the backclipping word that becomes "co". The syllable "-ba" in the end word "coba" word is cut. The word does not have the shift meaning between "coba (verb)" and "co (verb)". They are meaning to make an attempt or effort, and to use, do or test something in order to see whether it is satisfactory, effective, and enjoyable. Code 1d, the word "dengan" is the backclipping that becomes "deng". The syllabe "-an" in the word "dengan" is cut. "Dengan" (preposition) does not have shift meaning from "deng" (preposition) that are accompanied by (another person or thing), having or possessing (something), indicating the instrumen used to perform an action, in relation to.

2. Middle clipping

Table 2b. The middleclipping words of Papuan Malay

\begin{tabular}{ccc}
\hline Code & \multicolumn{2}{c}{ Word } \\
\cline { 2 - 3 } & Ind. & PM \\
\hline 1e & Pelan & Plan \\
\hline 1f & Tertutup & Tatutup \\
\hline $1 \mathrm{~g}$ & Terus & Trus \\
\hline
\end{tabular}

According to Veisbergs (1999), the middle clipping occurs in the middle syllable of word. Thus, the words of table $2 \mathrm{~b}$ includes to the middle clipping. In Code 1e the word "pelan" is a middle clipping that becomes "plan". The letter"-e" in the word "pelan" is cut. The word "pelan" (Adjective) does not have the shift meaning with "plan" (adjective). They still have the same meaning that is moving or operating, or designing to do so, only at a low speed; not quick or fast. For code 1f, The word "tertutup" is the middle clipping. The letter "ter-" has stressed of syllable and the letter "-er" has changed sound that becomes the new word "tatutup". The word" tertutup" (adjective) does not the shift meaning between "tatutup" (adjective) as locked or unopened. The word "terus" in code $\mathbf{1 g}$ is the middle clipping. The letter "-e" in the middle word of "terus" is cut that becomes "trus". The word" Terus" (adverb) does not the shift meaning between "trus" (adverb). Their meaning are after that, next, afterwards, in the case or therefore. 
3. Two Backlippings

Table 2c. The two backclipping word of Papuan Malay

\begin{tabular}{ccc}
\hline \multirow{2}{*}{ Code } & \multicolumn{2}{c}{ Word } \\
\cline { 2 - 3 } & Ind. & PM \\
\hline $1 \mathrm{~h}$ & Cukup penting & Cupen \\
\hline
\end{tabular}

In the table $2 \mathrm{c}$, the word "cukup penting" includes a compound word that have cut syllable in the back word or backclipping. The word formation can occur by combining the result of two backclipping (Veisbergs, 1999). The word "cukup" is cut in the syllable "-kup" and the word "penting" is cut in the syllable "-ting". Then, those words become the short word "cupen". They do not have the shift meaning between "cukup penting" (adjective) and "cupen" (adjective). They are meaning as follows: as the great value or concern, a person having great influence to use, and do or test something in order to see whether it is satisfactory, effective, enjoyable.

\section{Middle Clipping and Backclipping}

Table 2d. The middle clipping and backclipping words of Papuan Malay

\begin{tabular}{ccc}
\hline Code & \multicolumn{2}{c}{ Word } \\
\cline { 2 - 3 } & Ind. & PM \\
\hline $1 \mathrm{i}$ & Sebelah & Sebla \\
\hline $1 \mathrm{j}$ & Terbalik & Tabale \\
\hline
\end{tabular}

The complex case of English occurs on the combination of two types in the clipping word such as foreclipping and backclipping (Veisbergs, 1999). However in this case, the complex case of PM arises from the process of middle and back clippings as ilustrated in the table $2 \mathrm{~d}$. In code $1 \mathrm{i}$ the word "sebelah" has two kinds of cutting word that are middle clipping on the letter "-e", and backclipping on the letter"-h". Then two sylable "-bel" and "-lah" are stressed that becomes a new word "sebla". The word "sebelah" (preposition) does not the shift meaning between "sebla" (prepostion). Their meanings are in or into a position immediately to one side of beside. Moreover, code 1j $\mathbf{j}$ the word "terbalik" also has two kinds of the clipping word that are middle clipping on the letter "-r-", and the letter "-ik" is the backclipping. Both of the clippings are combined and becomes the new word "tabale". The word "tabale"is stressed on the syllable "-le". The word "terbalik" as adjective does not have the shift meaning between "tabale" (adjective)". Their meaning are the upper part where the lower part should be or in an inverted position. Those codes include to the complex case that have combination between middle and back clippings. 
5. Foreclipping

Table 2e. The foreclipping word of Papuan Malay

Code Word

Ind.

PM

There is unavailable word that has the foreclipping word

Based on the data of table 2, there are 31 words of clipping word. There are 4 types of clipping word from the data that are backclipping, middle clipping, two back clippings, and middle and back clipping. Through the data, there is not found the foreclipping in the Papuan Malay words. Thus, they will be shown deeply in table 3 as follows:

Table 3. The number of clipping word in Papuan Malay

\begin{tabular}{clcc}
\hline No & The types of clipping word & $\begin{array}{c}\text { The number } \\
\text { of PM }\end{array}$ & Percentage \\
\hline 1 & Backclipping & 23 words & $74.19 \%$ \\
\hline 2 & middle clipping & 5 words & $16.12 \%$ \\
\hline 3 & two backclippings & 1 word & $3.22 \%$ \\
\hline 4 & $\begin{array}{l}\text { middle clipping } \\
\text { backclipping }\end{array}$ & 2 words & $6.45 \%$ \\
\hline 5 & Foreclipping & 0 & 0 \\
\hline & Total & 31 words & $100 \%$ \\
\hline
\end{tabular}

\section{The Word Class of Clipping words in Papuan Malay}

After doing the deep analyze on the data, the researcher grouped the word class of clipping word. This study also concerns to know the word class of the words. On the table 4 shows the word class of the clipping word in Papuan Malay.

Tabel 4. The list of word class of the clipping word in Papuan Malay

\begin{tabular}{|c|c|c|c|c|c|c|c|}
\hline \multirow[b]{2}{*}{ Index } & \multicolumn{7}{|c|}{ Word Class } \\
\hline & (Int) & $(\mathrm{adv})$ & $(\mathrm{N})$ & (Adj) & $(\mathrm{V})$ & (Prep) & (Det) \\
\hline $\mathrm{A}$ & Ado & & Ade & & & & \\
\hline B & & & Bale & & Bale & & \\
\hline $\mathrm{C}$ & & & & Cupen & $\mathrm{Co}$ & & \\
\hline $\mathrm{D}$ & & & Dara & & Dapat & Deng & \\
\hline E-F & & & & vailable & & & \\
\hline & & & & & Goso & & \\
\hline $\mathrm{H}-\mathrm{I}$ & & & & vailable & & & \\
\hline $\mathrm{J}$ & & & & & Jato & & Jang \\
\hline $\mathrm{K}$ & & & Ko & & Kastunjuk & & \\
\hline $\mathrm{L}$ & & & & vailable & & & \\
\hline $\mathrm{M}$ & & & & & Mo & & \\
\hline
\end{tabular}




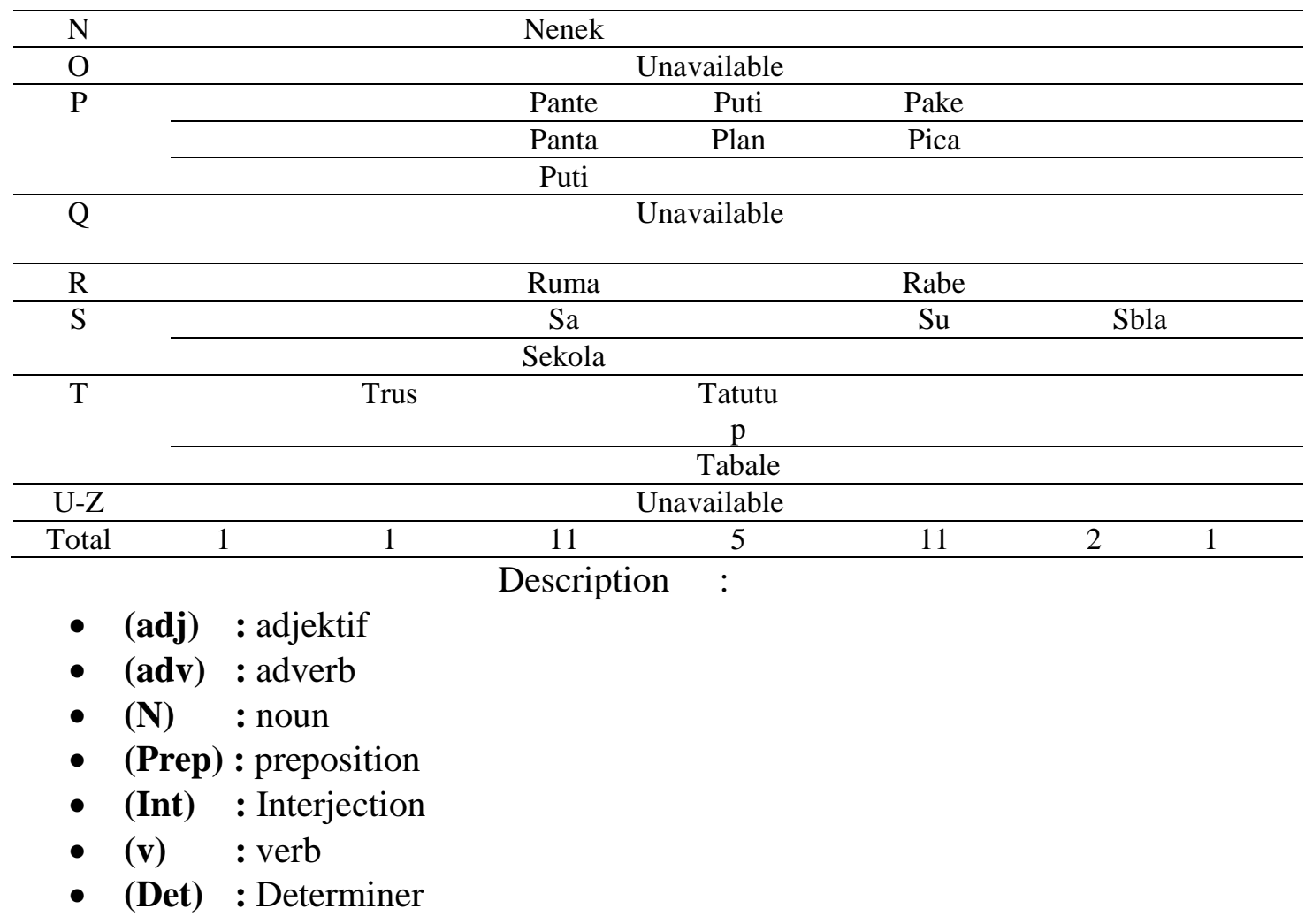

The processes of clipping word can not be predicted because the cutting process can be occured in the first or middle or back syllable as well as compound word (Bauer, 1984; Moehkardi, 2016). The result of table 2 presented the various of clipping word process such as backclipping, middle clipping, and complex case for two backclipping, and the combination between middle clipping as well as backclipping. The cutting syllables or letter can be influenced to the various factors. The first, the stressed word can give an impact to the cutting syllable as ilustrated in table $2 \mathrm{a}$ for $1 \mathrm{~b}$, the word "balik" is the backclipping word. "Balik" is stressed on the syllable "-lik and the letter "-k" of the word "Balik" is cut. Then, it becomes "Bale". Beside that, in table $2 \mathrm{~d}$ for code $1 \mathrm{i}$ shows the word "sebelah" that has two kinds of cutting word that are middle clipping on the letter "-e" and backclipping on the syllable "-h". Then it is stressed on the syllable "-bla" and becomes a new word "sebla". The process agree with Blevins's statement (cited in Aziz, 2011), the stress words create a new word with various structure patterns for instance $\mathrm{CV}, \mathrm{CVC}$, $\mathrm{VCV}, \mathrm{CVCV}, \mathrm{CVCVCV}$ and $\mathrm{CVCCV}$ and create the word that contain maximally trisyllabic such as the word ko (monosyllable), dara (disyllable) and tabale (trisyllable).

In addition, the language sound influences the process of clipping word. The segmental sounds such as intonation, tone, accent, and pressure or suprasegmental (Jamet, 2009; Nurhayati, 2016; Verhaar, 2012). In the case, the words "adik" is cut. The letter "-ik" that becomes "ade" that is affected by the suprasegmental sound. JELTL (Journal of English Language Teaching and Linguistics), 3(2), 2018 
The changing of sound words do not change the meaning, but only change the sound of the words. The last, the backclippings are the highest number of the word of PM, so the backclipping becomes the common way of clipping in PM. This case also occures on the clipping word in English (Veisbergs, 1999)

Furthermore the table 4, the data show the word class of PM that are one interjection (int), a adverb (adv), eleven nouns $(\mathrm{N})$, five adjectives (adj), eleven verbs (V), two prepositions (prep), and a determiner (det). As the syntactic dimension, basically the clipping form are nouns, adjectives, and verb, meanwhile adverbs, prepositions, interjections, and conjuctions rarely happen in the clipping word (Jamet, 2009; Tournier, 1985). Through the data, the word class of noun and verb place the highest number that are appropriate to the morphemic linguistics features of Papuan Malay mainly in verb (Supardi, 2014). However, the noun also becomes as the highest number of word class in PM and can be inserted as the one of morphemic linguistic system of PM. Therefore, the process of clipping words can create a new word that do not have the shift meaning. In addition, through the change of sound, as the a factor of clipping word, can be influenced by Papuan's culture and social that has the fast rhythm mainly in speaking, so some syllables of the word can get the reduction and the new word can be created in Papuan Malay.

\section{CONCLUSION}

From historical view, almost Papuans Malay comes from Indonesian and it is influenced by the speaking way of Papua speakers. Both of them still have the same meaning between the early word and after getting the cut. It can be influenced by the morphemic system of PM and speak with the fast rhythm. Through this study shows the process of word formation in Papuan Malay, mainly in clipping word and the backclipping words become the main role in Papuan Malay. This study only concerns on the clipping word of Papuan Malay in morphological review. Therefore, for the future study is recommended to analyze in pragmatic view of the Papuan Malay speech.

\section{REFERENCES}

Adams, V. (1973). An Introduction to Modern English Word-Formation (First edit). London: Longman.

Adelaar, K. Alexander \& Prentice, D. J. (1996). Malay: Its history, role and spread. In In Stephen A. Wurm and Peter Mühlhäusler and Darrell T. Tryon (eds.), Atlas of Languages of Intercultural Communication in the Pacific, Asia, and the Americas (pp. 673-693). Berlin: Mouton de Gruyter.

Agus A Alua; Ali Afudy; Presidium Dewan Papua (PDP). Sekretariat.; Sekolah Tinggi Filsafat Teologi (STFT) Fajar Timur. Biro Penelitian. (2006). Papua Barat dari pangkuan ke pangkuan: Suatu ikhtisar kronologis (Seri Pendidikan Politik Papua 1) (seri pendi). Jayapura: Sekretariat Presidium Dewan Papua; Biro Penelitian, STFT Fajar Timur. 
Aziz, A. Y. A. (2011). Suku Kata Dasar Dialek Kelantan Berdasarkan Teori Optimaliti. Journal of Language Studies, 11(2), 121-136.

Bauer, L. (1984). English Word Formation. Cambridge: Cambridge University Press.

Cannon, G. (1987). Historical Change and English Word-Formation: Recent Vocabulary. New York: Peter Lang.

Chauvel, R. (2002). Papua and Indonesia: Where Contending Nationalisms meet. In Damien Kingsbury \& Harry Aveling (eds). Autonomy and Disintegration in Indonesia. London: Rouledge Curzon Press.

Collins, J. T. (1998). Malay, world language: A short history. Kuala Lumpur: Dewan Bahasa dan Pustaka.

Dittmar, N. (1976). Sociolinguistics: A critical survey of theory and application. London: Edward Arnold.

Donohue, Mark \& Sawaki, Y. (2007). Papuan Malay Pronominals: Forms and Functions. Oceanic Linguistics, 46(1), 253-276.

Gau, S. (2011). Bahasa Melayu Maluku di Papua: Kerangka Pengenalan. Jurnal Elektronik, Jabatan Bahasa \& Kebudayaan Melayu, 3, 21-40.

Jamet, D. (2009). A Morphological approach to clipping in English: Can the Study of Clipping be Formalized? Lexicology and Phonology, HS 1.

Katamba, F. (1993). Morphology. London: Machilland Press LTD.

Kludge, A. (2014). A Grammar of Papuan Malay. Leiden University.

Moehkardi, R. R. D. (2016). Patterns and Meanings of English Words through Word Formation Processes of Acronyms, Clipping, Compound and Blending Found in Internet-Based Media. Humaniora, 28(3), 324-338.

Moeliono, A. (1963). Ragam bahasa di Irian Barat. In Koentjaraningrat and Harsja W.Bachtiar (eds.), Penduduk Irian Barat (Projek Penelitian Universitas Indonesia 102). Jakarta: Penerbitan Universitas.

Nida, E. A. (1949). Morphology: The descriptive analysis of words. Ann Arbor, MI: University of Michigan.

Nurhayati, D. A. W. (2016). Word Formation Processes and a Technique in Understanding Waria Slang Tulungagung. EFL Journal, 1(1).

Paauw, S. H. (2009). The Malay contact varieties of eastern Indonesia: A typological comparison. State University of New York.

Roosman, R. S. (1982). Pidgin Malay as Spoken in Irian Jaya.The Indonesian Quarterly, X/2. Waigani: University of Papua New Guine.

Rowley, C. D. (1972). The New Guinea villager: A retrospect from 1964. Melbourne: F. W. Cheshire.

Sudaryanto. (2015). Metode dan Aneka Teknik Analisis Bahasa. Yogyakarta: Sanata Dharma University Press.

Suharno, I. (1979). Some Notes on the Teaching of Standard Indonesian to Speakers of Irianese Indonesian. Bulletin of Irian Jaya, VIII(1), 3-33.

Supardi. (2014). The Linguistic Features of Malay Papuan in Indonesia; its History and Distinctive Peculiarities with Malay Indonesian. Global Journal of Human

JELTL (Journal of English Language Teaching and Linguistics), 3(2), 2018 
The Uniqueness formation of Papuan Malay in Morphologically

Social Science: Linguistics and Education, 14(3).

Tournier, J. (1985). Introduction descriptive à la lexicogénétique de l'anglais contemporain. Paris-Genève, Champion-Slatkine.

Veisbergs, A. (1999). Clipping in english and Latvian. Latvia: University of Latvia.

Verhaar, J. W. M. (2012). Asas-Asas Linguistik Umum. Yogyakarta: Gadjah Mada University Press. 